\title{
10-Gingerol inhibits proliferation and invasion of MDA-MB-231 breast cancer cells through suppression of Akt and $\mathrm{p38}^{\mathrm{MAPK}}$ activity
}

\author{
JI-HYE JOO $^{1 *}$, SEONG-SU HONG ${ }^{2 *}$, YOUNG-RAK CHO ${ }^{2}$ and DONG-WAN SEO ${ }^{1}$ \\ ${ }^{1}$ Department of Pharmacy, College of Pharmacy, Dankook University, Cheonan 31116 ; ${ }^{2}$ Gyeonggi Biocenter, \\ Gyeonggi Institute of Science and Technology Promotion, Suwon 16229, Republic of Korea
}

Received August 17, 2015; Accepted October 5, 2015

DOI: 10.3892/or.2015.4405

\begin{abstract}
In the present study, we investigated the roles and molecular mechanism of 10-gingerol, a phenolic compound isolated from Zingiber officinale, in regulating cell proliferation and invasion of MDA-MB-231 breast cancer cells. 10-gingerol treatment inhibited cell proliferation through downregulation of cell cycle regulatory proteins such as cyclin-dependent kinases and cyclins, and subsequent induction of $\mathrm{G}_{1}$ phase arrest. In addition, 10-gingerol treatment blocked cell invasion in response to mitogenic stimulation. These antitumor activities of 10-gingerol were mediated through inactivation of $\mathrm{Akt}$ and $\mathrm{p} 38^{\mathrm{MAPK}}$ activity, and suppression of epidermal growth factor receptor expression. Collectively, these findings demonstrate the pharmacological roles of 10-gingerol in regulating breast cancer cell growth and progression, and suggest further evaluation and development as a potential therapeutic agent for the prevention and treatment of breast cancer.
\end{abstract}

\section{Introduction}

Breast cancer is the most common type of cancer and the leading cause of cancer-related death in women (1). Approximately $70 \%$ of breast cancer patients are positive for estrogen receptor (ER) and these patients are suitable for anti-estrogen therapy. ER-negative breast cancer is often more malignant and aggressive than ER-positive breast cancer $(2,3)$. In addition, overexpression of epidermal growth factor receptor (EGFR) or human EGFR-2 (HER2) is well correlated to recurrent and metastatic breast cancers $(4,5)$. These receptors and their

Correspondence to: Professor Dong-Wan Seo, Laboratory of Biochemistry, Department of Pharmacy, College of Pharmacy, Dankook University, Pharmacy Hall, Rm 319, Cheonan 31116, Republic of Korea

E-mail: dwseomb@dankook.ac.kr

*Contributed equally

Key words: 10-gingerol, breast cancer, epidermal growth factor receptor down-stream signaling pathways are widely appreciated as the therapeutic targets for breast cancer.

Matrix metalloproteinases (MMPs) are a family of zinc-dependent proteases which are degrading all components of extracellular matrix as well as cell surface molecules, leading to regulating a variety of biological responses including cell migration, invasion, proliferation, apoptosis and angiogenesis (6-9). A number of MMPs are highly expressed in cancer tissue from breast cancer patients, and these expression patterns are closely associated with aggressive phenotypes and poor survival (10). Although early detection methods and multimodal approaches for breast cancer treatment have been made, there has been only modest progress in improving clinical outcomes for women with metastases. Therefore, detailed understanding of the biology and its molecular mechanism underlying the progression of the disease may provide insights into therapeutic targets and strategies for the treatment of breast cancer.

Ginger (Zingiber officinale Roscoe, Zingiberaceae) is a natural dietary rhizome that is widely used as a traditional medicinal herb as well as a flavoring agent. Ginger has various bioactive components such as gingerols, shogaols, paradols and zingerone, indicating the pharmacological roles in mediating anti-inflammatory and antitumor activities (11-14). Among the bioactive ingredients from ginger, 6-gingerol and 6-shogaol have been extensively reported to exert antitumor activities in a variety of cancers by inhibition of cell proliferation, migration and invasion or induction of apoptosis (15-20). 10-gingerol, one of the main phenolic compounds isolated from ginger, has been reported to possess antitumor activity against ovarian, colon, lung and prostate cancer cells by inhibition of cell proliferation or induction of apoptosis $(21,22)$, however, the effects and molecular mechanisms of 10-gingerol on breast cancer cell growth and progression are poorly understood. In the present study, we investigated the regulatory effects and signaling pathways of 10 -gingerol on cell proliferation and invasion in MDA-MB-231 breast cancer cells.

\section{Materials and methods}

Cell culture conditions. Human breast cancer cells (MDA-MB-231) from American Type Culture Collection (Manassas, VA, USA) were grown in $10 \%$ fetal bovine 
serum-Dulbecco's modified Eagle's medium (FBS-DMEM) (HyClone Laboratories, Logan, UT, USA).

Preparation of ginger extract and isolation of 10-gingerol. The dried Zingiber officinale (Z. officinale) was purchased from Gyeong-dong Oriental Medicine Market (Seoul, Republic of Korea), identified by Professor Joa Sub Oh (College of Pharmacy, Dankook University), and deposited at the herbarium of Gyeonggi Biocenter (Suwon, Republic of Korea). One thousand two hundred grams of Z. officinale were extracted three times with 15 liters of ethanol at room temperature for $24 \mathrm{~h}$. The extract was concentrated, suspended in water, and then partitioned three times with 1.5 liters of $n$-hexane. The $n$-hexane extract ( $24 \mathrm{~g}$ ) was subjected to silica gel column chromatography (Kieselgel 60, 70-230 mesh, $9 \times 25 \mathrm{~cm}$ ). Among eight fractions eluted from column chromatography, the sixth fraction $(0.4 \mathrm{~g})$ was further separated by semi-preparative HPLC (YMC-Pack ODS A column, 250x20 mm I.D.) eluting with acetonitrile-water (acetonitrile gradient from 50 to $100 \%$ ) at a flow speed of $20 \mathrm{ml} / \mathrm{min}$ to yield (S)-5-hydroxy-1-(4-hydroxy-3-methoxyphenyl)-3-tetrade canone (10-gingerol, $22.5 \mathrm{mg}$ ). ${ }^{1} \mathrm{H}$ - and ${ }^{13} \mathrm{C}$-NMR spectra were recorded on a Varian $500 \mathrm{MHz}$ NMR spectrometer (Bruker, Billerica, MA, USA).

Spectrometric analysis of 10-gingerol. ${ }^{1} \mathrm{H}-\mathrm{NMR}\left(\mathrm{CDCl}_{3}\right.$, $500 \mathrm{MHz}) \delta 6.83\left(1 \mathrm{H}, \mathrm{d}, J=8.0 \mathrm{~Hz}, \mathrm{H}-5^{\prime}\right), 6.69(1 \mathrm{H}, \mathrm{d}, J=2.0 \mathrm{~Hz}$, H-2'), $6.67\left(1 \mathrm{H}, \mathrm{dd}, J=8.0,2.0 \mathrm{~Hz}, \mathrm{H}-6^{\prime}\right), 4.03(1 \mathrm{H}, \mathrm{m}, \mathrm{H}-5), 3.88$ $\left(3 \mathrm{H}, \mathrm{s}, \mathrm{OCH}_{3}\right), 2.84(2 \mathrm{H}, \mathrm{brd}, J=7.5 \mathrm{~Hz}, \mathrm{H}-1), 2.75(2 \mathrm{H}, \mathrm{brd}$, $J=7.5 \mathrm{~Hz}, \mathrm{H}-2), 2.58(1 \mathrm{H}, \mathrm{dd}, J=17.5,3.0 \mathrm{~Hz}, \mathrm{H}-4 \mathrm{~b}), 2.50(1 \mathrm{H}$, dd, $J=17.0,9.0 \mathrm{~Hz}, \mathrm{H}-4 \mathrm{a}), 1.49$ (2H, m, H-6), 1.27-1.51 (14H, m, H-7-H-13), 0.89 (3H, t, J=7.0 Hz, H-14); ${ }^{13} \mathrm{C}-\mathrm{NMR}(\mathrm{CDCl}$, $125 \mathrm{MHz})$ \& 211.5 (C-3), $146.4\left(\mathrm{C}-3^{\prime}\right), 144.0\left(\mathrm{C}-4^{\prime}\right), 132.6$ (C-1'), 120.7 (C-6'), 114.4 (C-5'), 111.0 (C-2'), 67.7 (C-5), 55.9 $\left(\mathrm{OCH}_{3}\right), 49.4(\mathrm{C}-4), 45.4(\mathrm{C}-2), 36.5(\mathrm{C}-6), 31.9(\mathrm{C}-1), 29.6(\mathrm{C}-9)$, 29.5 (C-8), 29.3 (C-10), 29.28 (C-11), 25.5 (C-7), 22.7 (C-13), 14.1 (C-14). The structure of 10-gingerol is presented in Fig. 1A.

Reagents. The following pharmacological agents and antibodies were purchased from commercial sources: LY294002 (Merck Millipore, Billerica, MA, USA); SB203580 (Cayman Chemical, Ann Arbor, MI, USA); anti-phospho-extracellular signal-regulated kinase (ERK) (T202/Y204), anti-phospho-Akt (S473), anti-phospho-p70 ${ }^{\text {s6K }}$ (T421/S424) and anti-phospho-p38 mitogen-activated protein kinase (p38 $\left.{ }^{\mathrm{MAPK}}\right)$ (T180/Y182) (Cell Signaling, Beverly, MA, USA); anti-EGFR, anti-ERK, anti-Akt, anti-p70 ${ }^{\mathrm{S} 6 \mathrm{~K}}$, anti-p38 ${ }^{\mathrm{MAPK}}$, anti-Cdk4, anti-Cdk2, anti-cyclin D, anti-cyclin E, anti-actin antibodies, and mouse and rabbit IgG-horseradish peroxidase conjugates (Santa Cruz Biotechnology, Santa Cruz, CA, USA).

Cell proliferation assay. Subconfluent MDA-MB-231 cells, plated on 6-well plates $\left(5 \times 10^{4}\right.$ cells/well, BD Biosciences, Bedford, MA, USA), were serum-starved for $24 \mathrm{~h}$ in basal DMEM to synchronize cells in $\mathrm{G}_{1} / \mathrm{G}_{0}$ phase of cell cycle, pretreated with 10 -gingerol at different concentrations $(0.1-10 \mu \mathrm{M})$ in the presence or absence of LY294002 $(10 \mu \mathrm{M})$ or SB203580 $(5 \mu \mathrm{M})$ for $30 \mathrm{~min}$, and further incubated with $10 \%$ FBS for $24 \mathrm{~h}$. Following culture for $24 \mathrm{~h}$, the number of cells was quantified using trypan blue exclusion method

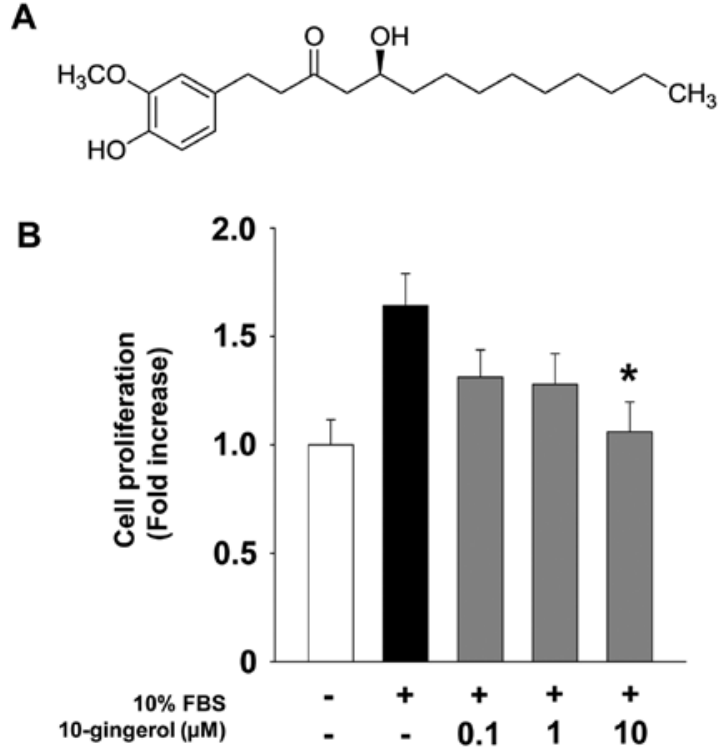

Figure 1. 10-Gingerol inhibits cell proliferation. (A) The chemical structure of 10-gingerol. (B) Cell proliferation assay was performed as described in Materials and methods. Quiescent MDA-MB-231 cells were pretreated with 10-gingerol at different concentrations $(0.1-10 \mu \mathrm{M})$ for $30 \mathrm{~min}$, followed by $10 \%$ serum stimulation for $24 \mathrm{~h}$. The results from triplicate determinations $($ mean $\pm \mathrm{SD})$ are presented as the fold-increase of untreated controls. Statistical significance is indicated ( $\mathrm{P}<0.05$, compared with $10 \%$ serum-treated cells).

as described previously $(23,24)$. The results from triplicate determinations (mean \pm standard deviation) are presented as the fold-increase of untreated controls.

Cell cycle analysis. Serum-starved MDA-MB-231 cells, plated on 6 -well plates $\left(5 \times 10^{4}\right.$ cells/well), were pretreated with 10 -gingerol $(10 \mu \mathrm{M})$ for $30 \mathrm{~min}$, followed by $10 \%$ FBS for $24 \mathrm{~h}$. Cells were harvested with trypsin-EDTA, rinsed with phosphate buffered saline (PBS), and then fixed with ice-cold $70 \%$ ethanol for $3 \mathrm{~h}$. After washing with PBS, cells were stained with Muse ${ }^{\mathrm{TM}}$ cell cycle reagent. The profile of cells in the $\mathrm{G}_{1} / \mathrm{G}_{0}, \mathrm{~S}$ and $\mathrm{G}_{2} / \mathrm{M}$ phases of the cell cycle was analyzed with a Muse ${ }^{\mathrm{TM}}$ cell analyzer (Merck Millipore) (25).

Western blot analysis. Serum-starved cells in $100 \mathrm{~mm}$ dishes (BD Biosciences) were incubated for $15 \mathrm{~min}$ or $24 \mathrm{~h}$ in $10 \%$ FBS in the presence or absence of 10-gingerol. Cells were rinsed twice with ice-cold PBS and lysed by incubation in $50 \mathrm{mM}$ Tris- $\mathrm{HCl}$ (pH 7.4), $150 \mathrm{mM} \mathrm{NaCl}, 10 \%$ glycerol, $1 \%$ Triton X-100, 1 mM EDTA, $100 \mu \mathrm{g} / \mathrm{ml}$ 4-(2-aminoethyl) benzenesulfonyl fluoride, $10 \mu \mathrm{g} / \mathrm{ml}$ aprotinin, $1 \mu \mathrm{g} / \mathrm{ml}$ pepstatin $\mathrm{A}, 0.5 \mu \mathrm{g} / \mathrm{ml}$ leupeptin, $80 \mathrm{mM} \beta$-glycerophosphate, $25 \mathrm{mM}$ sodium fluoride and $1 \mathrm{mM}$ sodium orthovanadate for $30 \mathrm{~min}$ at $4^{\circ} \mathrm{C}$. Cell lysates were clarified at $13,000 \mathrm{x} \mathrm{g}$ for $20 \mathrm{~min}$ at $4^{\circ} \mathrm{C}$, and the supernatants were subjected to western blot analysis as described previously $(26,27)$. Bands of interest were integrated and quantified by the use of National Institutes of Health (NIH) ImageJ version 1.34s software.

Invasion assay. The upper side of the Transwell insert (Costar, $6.5 \mathrm{~mm}$ diameter insert, $8 \mu \mathrm{m}$ pore size) (Corning Inc., Corning, NY, USA) was coated with $50 \mu 1$ of $1 \mathrm{mg} / \mathrm{ml}$ 
A
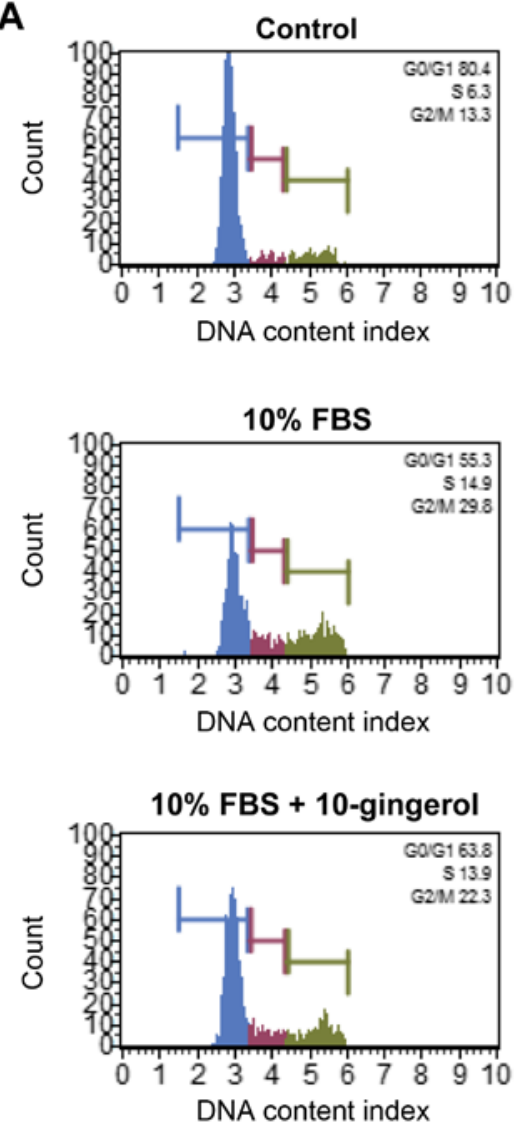

B

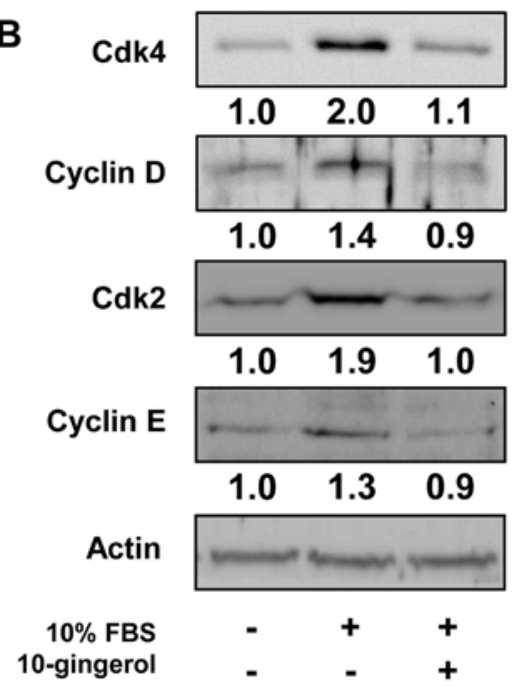

Figure 2. 10-Gingerol regulates cell cycle progression. Cell cycle (A) and western blot analysis (B) were performed as described in Materials and methods. Quiescent MDA-MB-231 cells were treated with 10-gingerol $(10 \mu \mathrm{M})$ for $30 \mathrm{~min}$, followed by $10 \%$ serum stimulation for $24 \mathrm{~h}$. Integrated density values were normalized to untreated controls. Results shown are representative of at least three independent experiments.

Matrigel (BD Biosciences) diluted in serum-free DMEM at $37^{\circ} \mathrm{C}$. Aliquots $(100 \mu \mathrm{l})$ of MDA-MB-231 cells $\left(6 \times 10^{5}\right.$ cells $\left./ \mathrm{ml}\right)$ resuspended in serum-free DMEM were added to the upper compartment of the Matrigel-coated Transwell and $600 \mu \mathrm{l}$ of serum-free DMEM were added to the lower compartment. After serum starvation for $2 \mathrm{~h}$, MDA-MB-231 cells were pretreated with 10-gingerol $(10 \mu \mathrm{M})$, LY294002 $(10 \mu \mathrm{M})$ or
SB203580 $(5 \mu \mathrm{M})$ for $30 \mathrm{~min}$, followed by serum stimulation for $14 \mathrm{~h}$. The inserts were fixed with methanol and using a cotton-tipped swab the non-invasive cells were removed from the top of the membrane. After staining with $0.04 \%$ Giemsa solution (Sigma-Aldrich, St. Louis, MO, USA), the number of invasive cells was determined from six different fields using objective magnification, x200 (28).

Zymogram analysis. Activities of MMPs were measured by zymography $(29,30)$. Aliquots of conditioned medium were diluted in sample buffer, and applied to $10 \%$ polyacrylamide gels containing $1 \mathrm{mg} / \mathrm{ml}$ gelatin (Sigma-Aldrich) as a substrate. After electrophoresis, the gels were incubated in $2.5 \%$ Triton X-100 for $1 \mathrm{~h}$ to remove SDS and allow re-naturalization of MMPs, and further incubated in developing buffer containing $50 \mathrm{mM}$ Tris- $\mathrm{HCl}(\mathrm{pH} 7.5), 10 \mathrm{mM} \mathrm{CaCl}_{2}$, and $150 \mathrm{mM} \mathrm{NaCl}$ for $15 \mathrm{~h}$ at $37^{\circ} \mathrm{C}$. The gels were stained with 0.5\% Coomassie Brilliant Blue R-250 in 30\% methanol-10\% acetic acid for $2 \mathrm{~h}$ and followed by destaining with $30 \%$ methanol-10\% acetic acid. Gelatinolytic activities were detected as unstained bands against the background of the Coomassie Blue-stained gelatin.

Statistical analysis. Statistical analysis was performed using Student's t-test and was based on at least three different experiments. The results were considered to be statistically significant at $\mathrm{P}<0.05$.

\section{Results}

10-Gingerol inhibits cell proliferation via downregulation of cell cycle regulatory proteins. We first investigated the effect of 10-gingerol on cell proliferation in ER-negative MDA-MB-231 breast cancer cells. 10-gingerol treatment inhibited mitogen-stimulated cell proliferation in a dose-dependent manner (Fig. 1B), and did not alter cell viability at the highest concentration used in this study (data not shown), indicating that 10-gingerol-mediated inhibition of cell proliferation is not mediated by the induction of apoptosis or cytotoxicity. In addition, our initial experiments indicate that 10-gingerol markedly inhibited ER-positive MCF-7 breast cancer cell proliferation to levels similar to that observed in MDA-MB-231 cells (data not shown). These findings demonstrate the anti-proliferative activity of 10-gingerol in breast cancer cells, independently of ER expression status. We next examined the effect of 10-gingerol on the cell cycle by DNA content analysis (Fig. 2A). Mitogenic stimulation for $24 \mathrm{~h}$ increased the percentage of cells in S phase (6.3 vs. 14.9\%) and $\mathrm{G}_{2} / \mathrm{M}$ phase (13.3 vs. $29.8 \%$ ), and simultaneously decreased the percentage of cells in $\mathrm{G}_{1}$ phase (80.4 vs. 55.3\%), compared with untreated controls. However, 10-gingerol prevented the increase in $S$ phase (14.9 vs. $13.9 \%$ ) and $\mathrm{G}_{2} / \mathrm{M}$ phase (29.8 vs. $22.3 \%$ ), and the decrease in $\mathrm{G}_{1}$ phase (55.3 vs. $63.8 \%$ ) associated with mitogenic stimulation. These observations suggest that 10 -gingerol inhibits the transition from $\mathrm{G}_{1}$ phase of the cell cycle to $S$ phase, resulting in $G_{1}$ arrest, which is well correlated with inhibition of cell proliferation (Fig. 1B). Based on these findings, we analyzed the changes of cell cycle regulatory proteins in 10-gingerol-treated MDA-MB-231 cells. 10-Gingerol treatment markedly suppressed mitogen-induced 
A
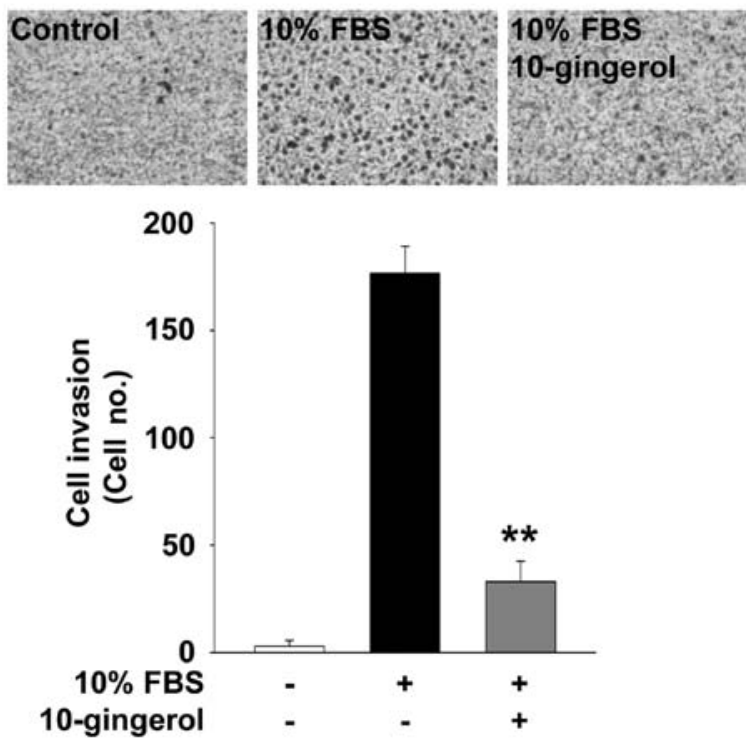

B

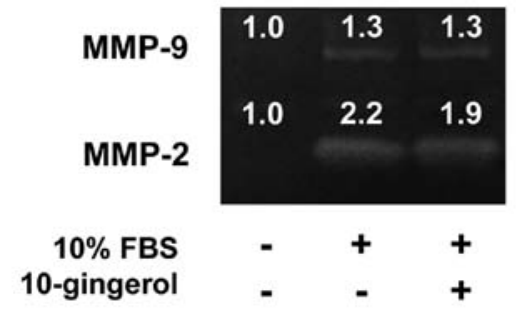

Figure 3. 10-Gingerol inhibits cell invasion. In vitro Transwell invasion (A) and zymogram analysis (B) were performed as described in Materials and methods. (A) Quiescent MDA-MB-231 cells were treated with 10-gingerol $(10 \mu \mathrm{M})$ for $30 \mathrm{~min}$, followed by $10 \%$ serum stimulation for $14 \mathrm{~h}$. The number of invasive cells was determined by counting six different fields of cells (magnification, $\mathrm{x} 200$ ). Results from six independent experiments (mean \pm SD) are presented as the number of invasive cells. Statistical significance is indicated $\left({ }^{* *} \mathrm{P}<0.01\right.$, compared with $10 \%$ serum-treated cells). (B) Gelatin zymogram analysis was carried out by using conditioned media from cell culture treated as in panel A. Zymogram gel loading was normalized to total protein concentration. Integrated density values were normalized to untreated controls. Results shown are representative of at least three independent experiments.

expression of cyclin-dependent kinases (Cdks) and cyclins to levels observed in untreated controls (Fig. 2B). Collectively, these findings indicate that 10 -gingerol downregulates the expression of cell cycle regulatory proteins, resulting in inhibition of cell cycle progression and proliferation.

10-Gingerol inhibits cell invasion. We next examined the effect of 10-gingerol on cell invasion which plays pivotal roles in cancer progression. 10-Gingerol treatment markedly inhibited mitogen-induced invasion of MDA-MB-231 cells (Fig. 3A). Expression and activation of MMPs have been reported to enhance cell migration and invasion by degrading the components of extracellular matrix and cell surfaces (6-9). Based on 10-gingerol-mediated inhibition of cell invasion, we examined the activity of MMPs in MDA-MB-231 cells. 10 -gingerol treatment marginally inhibited the activity of MMP-2, but not MMP-9, suggesting that inhibition of cell invasion by 10-gingerol is mediated, at least in part, through the suppression of MMP-2 activity (Fig. 3B).

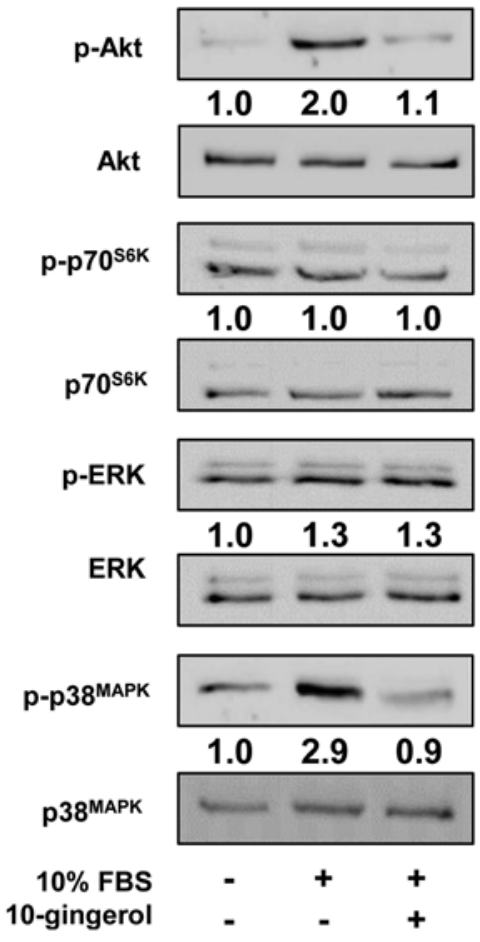

Figure 4. 10-Gingerol inhibits mitogen-induced activation of Akt and $\mathrm{p} 38^{\mathrm{MAPK}}$ Quiescent MDA-MB-231 cells were pretreated with 10-gingerol $(10 \mu \mathrm{M})$ for $30 \mathrm{~min}$, followed by $10 \%$ serum stimulation for $15 \mathrm{~min}$. Integrated density values were normalized to untreated controls. Results shown are representative of three independent experiments.

Regulatory effects of 10-gingerol on cell proliferation and invasion are mediated through inactivation of Akt- and p3 $38^{M A P K}$-dependent signaling pathways. To investigate the molecular mechanism by which 10 -gingerol modulates cell proliferation and invasion, we examined the changes in activation of intracellular signaling pathways such as Akt, $\mathrm{p} 70^{\mathrm{S} 6 \mathrm{~K}}$, ERK and $\mathrm{p} 38^{\mathrm{MAPK}}$ in 10-gingerol-treated MDA-MB-231 cells. Mitogenic stimulation increased the phosphorylation/activation of Akt, ERK and $\mathrm{p} 38^{\mathrm{MAPK}}$, but not that of $\mathrm{p} 70^{\mathrm{S} 6 \mathrm{~K}}$, as compared with unstimulated controls. 10-Gingerol treatment markedly inhibited the phosphorylation of Akt and $\mathrm{p} 38^{\mathrm{MAPK}}$ in MDA-MB-231 cells (Fig. 4). Finally, pretreatment of cells with LY294002, an inhibitor of phosphoinositide 3-kinase (PI3K)/Akt pathway, or SB203580, an inhibitor of p38 $8^{\mathrm{MAPK}}$ pathway, mimicked the suppressive effects of 10-gingerol on cell proliferation and invasion in MDA-MB-231 cells (Fig. 5A and B). Co-treatment with 10-gingerol did not significantly enhance the anti-proliferative activity of these pharmacological inhibitors, indicating that 10 -gingerol and these inhibitors may share similar roles and mechanisms of action in regulating cellular processes of MDA-MB-231 cells.

10-Gingerol suppresses the expression of EGFR. The EGFR is a receptor tyrosine kinase which is highly expressed or activated in various types of human cancers including breast cancer $(4,31)$. Therefore, EGFR and its down-stream signaling pathways have been known as key therapeutic targets for cancer treatment. 10-Gingerol treatment markedly suppressed mitogen-induced expression of EGFR in MDA-MB-231 cells to levels observed in unstimulated controls (Fig. 5C). Taken 
A

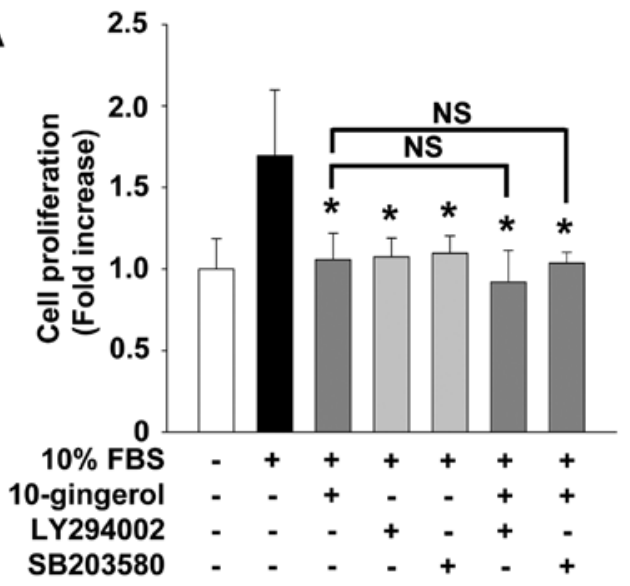

B

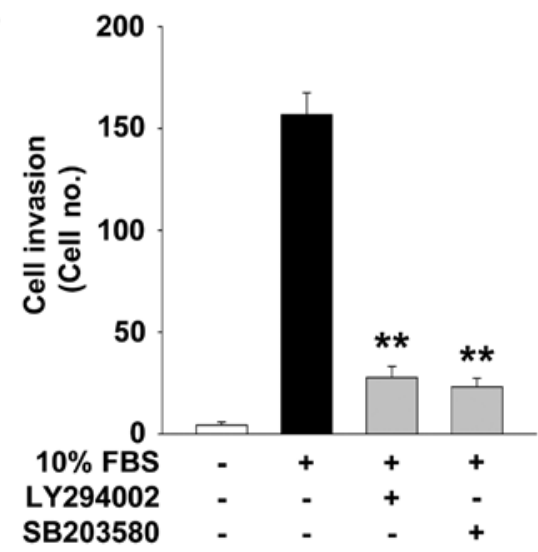

C

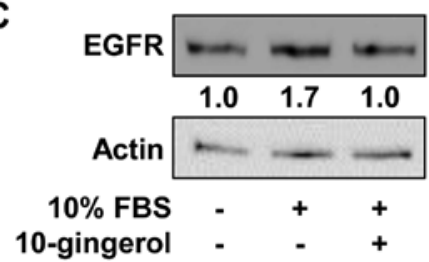

Figure 5. 10-Gingerol inhibits cell proliferation and invasion through the inactivation of Akt and $\mathrm{p} 38^{\mathrm{MAPK}}$. Cell proliferation (A), invasion (B) and western blot analysis (C) were performed as described in Materials and methods. Quiescent MDA-MB-231 cells were pretreated with 10-gingerol $(10 \mu \mathrm{M})$ for $30 \mathrm{~min}$ in the presence or absence of LY294002 $(10 \mu \mathrm{M})$ or SB203580 $(5 \mu \mathrm{M})$, followed by $10 \%$ serum stimulation for $24 \mathrm{~h}$ (A and C) or $14 \mathrm{~h}$ (B). Integrated density values were normalized to untreated controls. Results shown are representative of at least three independent experiments. Statistical significance is indicated $\left({ }^{*} \mathrm{P}<0.05,{ }^{* *} \mathrm{P}<0.01\right.$, compared with $10 \%$ serum-treated cells; NS, not significant).

together, these observations suggest that anti-proliferative and anti-invasive activities of 10-gingerol in MDA-MB-231 breast cancer cells might be correlated with suppression of EGFR expression.

\section{Discussion}

Ginger has popularly been consumed as a flavoring agent and traditional medicinal herb for the treatment of a variety of disorders such as pain, inflammation, asthma, hypertension and diabetes through antioxidative, anti-inflammatory and anti-hyperglycemic activities (32). In addition, antitumor effects of ginger and its components including gingerols and shogaols have been reported in various types of human cancers (11-13,15-22). However, no pharmacological effects and detailed molecular mechanisms of 10-gingerol on breast cancer cell proliferation and invasion have been clearly investigated to date.

Data presented in this study show that 10 -gingerol treatment markedly inhibits the proliferation of breast cancer cells through downregulation of cell cycle regulatory proteins such as Cdks and cyclins, and this anti-proliferative activity of 10-gingerol seems to be independent of ER expression status. Moreover, 10-gingerol strongly abrogates breast cancer cell invasion, which might be mediated partially through inhibition of MMP-2 activity. Previous studies demonstrate that 6-gingerol or 6-shogaol inhibits cell invasion in different cell lines including breast cancer and liver cancer by differential modulation of MMP-2 and MMP-9 activity $(15,18,33)$. These findings indicate that the regulatory effect of bioactive phenolic components including 10-gingerol, 6-gingerol or 6-shogaol on MMP activity might be dependent on the cell/tissue types or the changes in expression of endogenous inhibitors, tissue inhibitors of metalloproteinases (34).

EGFR is frequently overexpressed in ER-negative breast cancer patients with aggressive phenotype and poor clinical outcome, indicating the potential role of EGFR and its down-stream signaling components as therapeutic targets for the treatment of ER-negative breast cancers (35). EGFR-dependent down-stream signaling pathways include the activation of PI3K/Akt, Ras/Raf/ERK, p38 $8^{\mathrm{MAPK}}$, c-Jun $\mathrm{N}$-terminal kinase, phospholipase $\mathrm{C} \gamma$, and focal adhesion kinase, which are implicated in cell proliferation, survival, migration and invasion (4). In the present study we demonstrated that 10-gingerol-mediated inhibition of breast cancer cell proliferation and invasion is mediated through inactivation of Akt and $\mathrm{p} 38^{\mathrm{MAPK}}$ activity as evidenced by treatment with LY294002 and SB203580, respectively. Furthermore, 10 -gingerol treatment markedly suppressed the expression of EGFR in ER-negative MDA-MB-231 cells as well as ER-positive MCF-7 cells (data not shown). This finding is similar to the patterns of 10-gingerol inhibition of cell proliferation in both ER-negative MDA-MB-231 and ER-positive MCF-7 cells. In conclusion, we demonstrate for the first time that 10-gingerol inhibits mitogen-induced Akt and $\mathrm{p} 38^{\mathrm{MAPK}}$ phosphorylation/activation and EGFR expression, leading to inhibition of breast cancer cell proliferation and invasion. These findings warrant further evaluation and preclinical development of 10-gingerol as a potent antitumor agent in combination with conventional or molecular targeted therapies for the treatment of breast cancer.

\section{Acknowledgements}

The present study was supported by the research fund of Dankook University in 2014.

\section{References}

1. Torre LA, Bray F, Siegel RL, Ferlay J, Lortet-Tieulent J and Jemal A: Global cancer statistics, 2012. CA Cancer J Clin 65: 87-108, 2015 . 
2. Guo M, Wang M, Deng H, Zhang X and Wang Z-Y: A novel anticancer agent Broussoflavonol B downregulates estrogen receptor (ER)- $\alpha 36$ expression and inhibits growth of ER-negative breast cancer MDA-MB-231 cells. Eur J Pharmacol 714: 56-64, 2013.

3. Munoz J, Wheler J and Kurzrock R: Expression of estrogen and progesterone receptors across human malignancies: New therapeutic opportunities. Cancer Metastasis Rev: Dec 28, 2014 (Epub ahead of print).

4. Masuda H, Zhang D, Bartholomeusz C, Doihara $\mathrm{H}$, Hortobagyi GN and Ueno NT: Role of epidermal growth factor receptor in breast cancer. Breast Cancer Res Treat 136: 331-345, 2012.

5. Dawood S, Broglio K, Buzdar AU, Hortobagyi GN and Giordano SH: Prognosis of women with metastatic breast cancer by HER 2 status and trastuzumab treatment: An institutional-based review. J Clin Oncol 28: 92-98, 2010

6. Bourboulia D and Stetler-Stevenson WG: Matrix metalloproteinases (MMPs) and tissue inhibitors of metalloproteinases (TIMPs): Positive and negative regulators in tumor cell adhesion. Semin Cancer Biol 20: 161-168, 2010.

7. Kessenbrock K, Plaks V and Werb Z: Matrix metalloproteinases: Regulators of the tumor microenvironment. Cell 141: 52-67, 2010.

8. Stetler-Stevenson WG: Tissue inhibitors of metalloproteinases in cell signaling: Metalloproteinase-independent biological activities. Sci Signal 1: re6, 2008.

9. Vandenbroucke RE and Libert C: Is there new hope for therapeutic matrix metalloproteinase inhibition? Nat Rev Drug Discov 13: 904-927, 2014

10. Hadler-Olsen E, Winberg J-O and Uhlin-Hansen L: Matrix metalloproteinases in cancer: Their value as diagnostic and prognostic markers and therapeutic targets. Tumour Biol 34: 2041-2051, 2013

11. Oyagbemi AA, Saba AB and Azeez OI: Molecular targets of [6]-gingerol: Its potential roles in cancer chemoprevention. Biofactors 36: 169-178, 2010.

12. Shukla Y and Singh M: Cancer preventive properties of ginger: A brief review. Food Chem Toxicol 45: 683-690, 2007.

13. Baliga MS, Haniadka R, Pereira MM, D'Souza JJ, Pallaty PL, Bhat HP and Popuri S: Update on the chemopreventive effects of ginger and its phytochemicals. Crit Rev Food Sci Nutr 51: 499-523, 2011

14. Lee T-Y, Lee K-C, Chen S-Y and Chang H-H: 6-Gingerol inhibits ROS and iNOS through the suppression of PKC- $\alpha$ and NF-kappaB pathways in lipopolysaccharide-stimulated mouse macrophages. Biochem Biophys Res Commun 382: 134-139, 2009.

15. Lee HS, Seo EY, Kang NE and Kim WK: [6]-Gingerol inhibits metastasis of MDA-MB-231 human breast cancer cells. J Nutr Biochem 19: 313-319, 2008

16. Lee S-H, Cekanova M and Baek SJ: Multiple mechanisms are involved in 6-gingerol-induced cell growth arrest and apoptosis in human colorectal cancer cells. Mol Carcinog 47: 197-208, 2008

17. Brown AC, Shah C, Liu J, Pham JTH, Zhang JG and Jadus MR: Ginger's (Zingiber officinale Roscoe) inhibition of rat colonic adenocarcinoma cells proliferation and angiogenesis in vitro. Phytother Res 23: 640-645, 2009.

18. Weng C-J, Wu C-F, Huang H-W, Ho C-T and Yen G-C: Anti-invasion effects of 6-shogaol and 6-gingerol, two active components in ginger, on human hepatocarcinoma cells. Mol Nutr Food Res 54: 1618-1627, 2010.

19. Kim MO, Lee M-H, Oi N, Kim SH, Bae KB, Huang Z, Kim DJ, Reddy K, Lee SY, Park SJ, et al: [6]-shogaol inhibits growth and induces apoptosis of non-small cell lung cancer cells by directly regulating Akt1/2. Carcinogenesis 35: 683-691, 2014.
20. Fan J, Yang X and Bi Z: 6-Gingerol inhibits osteosarcoma cell proliferation through apoptosis and AMPK activation. Tumour Biol 36: 1135-1141, 2015.

21. Kim JS, Lee SI, Park HW, Yang JH, Shin TY, Kim YC, Baek NI, Kim SH, Choi SU, Kwon BM, et al: Cytotoxic components from the dried rhizomes of Zingiber officinale Roscoe. Arch Pharm Res 31: 415-418, 2008.

22. Sang S, Hong J, Wu H, Liu J, Yang CS, Pan MH, Badmaev V and Ho CT: Increased growth inhibitory effects on human cancer cells and anti-inflammatory potency of shogaols from Zingiber officinale relative to gingerols. J Agric Food Chem 57: 10645-10650, 2009.

23. Cho Y-R, Choi SW and Seo D-W: The in vitro antitumor activity of Siegesbeckia glabrescens against ovarian cancer through suppression of receptor tyrosine kinase expression and the signaling pathways. Oncol Rep 30: 221-226, 2013.

24. Kim H-J, Ko H-Y, Choi S-W and Seo D-W: Anti-angiogenic effects of Siegesbeckia glabrescens are mediated by suppression of the Akt and p70S6K-dependent signaling pathways. Oncol Rep 33: 699-704, 2015.

25. Lee HN, Kim J-K, Kim JH, Lee SJ, Ahn EK, Oh JS and Seo DW: A mechanistic study on the anti-cancer activity of ethyl caffeate in human ovarian cancer SKOV-3 cells. Chem Biol Interact 219: 151-158, 2014.

26. Kim SH, Cho Y-R, Kim H-J, Oh JS, Ahn EK, Ko HJ, Hwang BJ, Lee SJ, Cho Y, Kim YK, et al: Antagonism of VEGF-A-induced increase in vascular permeability by an integrin $\alpha 3 \beta 1-S h p-1-$ cAMP/PKA pathway. Blood 120: 4892-4902, 2012.

27. Kim H-J, Cho Y-R, Kim SH and Seo D-W: TIMP-2-derived 18-mer peptide inhibits endothelial cell proliferation and migration through cAMP/PKA-dependent mechanism. Cancer Lett 343: 210-216, 2014

28. Lee HN, Joo J-H, Oh JS, Choi SW and Seo D-W: Regulatory effects of Siegesbeckia glabrescens on non-small cell lung cancer cell proliferation and invasion. Am J Chin Med 42: 453-463, 2014.

29. Yoon HJ, Cho Y-R, Joo J-H and Seo D-W: Knockdown of integrin $\alpha 3 \beta 1$ expression induces proliferation and migration of non-small cell lung cancer cells. Oncol Rep 29: 662-668, 2013.

30. Cho Y-R, Kim JH, Kim J-K, Ahn EK, Ko HJ, In JK, Lee SJ, Bae U, Kim YK, Oh JS, et al: Broussonetia kazinoki modulates the expression of VEGFR-2 and MMP-2 through the inhibition of ERK, Akt and p70S6K dependent signaling pathways: Its implication in endothelial cell proliferation, migration and tubular formation. Oncol Rep 32: 1531-1536, 2014.

31. Jamdade VS, Sethi N, Mundhe NA, Kumar P, Lahkar M and Sinha N: Therapeutic targets of triple-negative breast cancer: A review. Br J Pharmacol 172: 4228-4237, 2015.

32. Ali BH, Blunden G, Tanira MO and Nemmar A: Some phytochemical, pharmacological and toxicological properties of ginger (Zingiber officinale Roscoe): A review of recent research. Food Chem Toxicol 46: 409-420, 2008.

33. Weng C-J, Chou C-P,Ho C-T and Yen G-C: Molecular mechanism inhibiting human hepatocarcinoma cell invasion by 6 -shogaol and 6-gingerol. Mol Nutr Food Res 56: 1304-1314, 2012.

34. Seo D-W, Li H, Guedez L, Wingfield PT, Diaz T, Salloum R, Wei BY and Stetler-Stevenson WG: TIMP-2 mediated inhibition of angiogenesis: An MMP-independent mechanism. Cell 114: 171-180, 2003

35. Burness ML, Grushko TA and Olopade OI: Epidermal growth factor receptor in triple-negative and basal-like breast cancer: Promising clinical target or only a marker? Cancer J 16: 23-32, 2010. 